\title{
Improvement of LPKA Class 1 Palembang Electronic Dashboard with Field Performance Monitoring
}

\author{
Hendra Hadiwijaya ${ }^{1}$ Febrianty Febrianty ${ }^{1}$ Rezania Agramanisti Azdy,
}

\author{
${ }^{1}$ Accounting Study Program, Palembang Palcomtech Polytechnic, Indonesia \\ ${ }^{2 *}$ Informatics Study Program, STMIK PalComTech, Indonesia \\ ${ }^{*}$ Corresponding author. Email: rezania@palcomtech.ac.id
}

\begin{abstract}
LPKA Class 1 Palembang was included in the Top 452019 Public Service Innovations in the Public Service Innovation Competition organized by the Ministry of Administrative Reform and Bureaucratic Reform. LPKA Class 1 Palembang continues to strive to improve its performance, especially in the field of public services in order to realize the achievement of a Corruption Free Area (WBK) and a Clean and Serving Bureaucratic Region (WBBM). One of the efforts that have been made in realizing the achievement of WBK and WBBM is by utilizing information technology with the availability of an electronic dashboard that can be used to manage service data at LPKA Class 1 Palembang. The e-dashboard that has been built focuses on presenting data in the form of service performance to the public that has been carried out by LPKA Class 1 Palembang, but does not yet have a function to monitor the activities of LPKA employees every day. This study aims to develop an electronic dashboard on LPKA Class 1 Palembang which is contained in previous research by adding functions in the form of reporting and monitoring the daily activities of LPKA Class 1 Palembang employees. The research was carried out in several stages, namely exploring feedback from users to readjust the e-dashboard to the user's latest needs, and developing the e-dashboard using the stages of system development in the form of planning, designing, coding, and testing. System testing is carried out to measure user responses based on their user experience using the User Experience Questionnaire (UEQ) method. The results of the research are improvements to the e-dashboard system with the addition of functions in the form of reporting daily activities so that the leadership can monitor the activities of LPKA employees every day. The test results using UEQ show the user rating Good for the attractiveness, efficiency, stimulation, and novelty scales with values of $1.61,1.65,1.43$, and 1.49. Meanwhile, on the Perspicuity and Dependability scale, the results of the user response measurement obtained the Above Average criteria with values of 1.65 and 1.44 .
\end{abstract}

Keywords: E-Dashboard, LPKA Palembang, Monitoring, Field Performance

\section{INTRODUCTION}

LPKA Class 1 Palembang is a special child correctional institution located in Palembang, South Sumatra. In 2019, LPKA Class 1 Palembang was included in the Top 452019 Public Service Innovations in the Public Service Innovation Competition through

units that meet most of the criteria in change management, management arrangement, HR management system structuring, strengthening supervision, and strengthening performance accountability, and WBM is a predicate given to work units that fulfill most of the requirements. change management, governance arrangement, HR management system arrangement, strengthening
One Agency One Innovation organized by the Ministry of Administrative Reform and Bureaucratic Reform. LPKA Class 1 Palembang continues to strive to reform the bureaucracy and improve its service performance in order to realize the achievement of a Corruption Free Area (WBK) and a Clean and Serving Bureaucratic Region (WBBM). WBK is a predicate given to work supervision, strengthening performance accountability, and strengthening the quality of public services [1]. WBK and WBBM is a process that can be encouraged in the realization of the Integrity Zone with the main objectives to be achieved are [2]:

1. The realization of a government//judicial institution that is clean and free from corruption, collusion and nepotism. 
2. The realization of Public Service Quality Improvement.

In enforcing the Integrity Zone, one of the main targets that is the focus of the implementation of bureaucratic reform is the realization of improving the quality of public services to the community, measured by the perceived value of service quality (service survey) [3]. The services provided by the Correctional Institution are in the form of health services, services for the needs of prisoners, services for the rights of prisoners, services providing security, visiting services, and services in providing information needed by the community (the families of the prisoners themselves) [4].

One of the efforts that have been made in realizing the achievement of WBK and WBBM is by utilizing information technology with the availability of an electronic dashboard that can be used to manage service data at LPKA Class 1 Palembang [5]. The term dashboard itself was originally used to refer to a board in front of the train that stops mud from splashing into the vehicle. Then the car uses the term dashboard to display information to the driver about the status of various systems on the car [6]. In an organization, the term dashboard is used to describe a system that visualizes data so that it is useful in decision making [7]. Along with the development of information technology, the presentation of the dashboard can be done digitally or also known as an electronic dashboard (e-dashboard). The digital dashboard is an intuitive and easy-to-use front-end for monitoring, analyzing, and optimizing critical business activities enabling users at every level to improve their decisions [8][9].

The electronic dashboard found in LPKA Class 1 Palembang has functions that can be used to register online visits, make complaints, apply for remission, assimilation, conditional leave, leave before being released, and leave to visit family [5]. The e-dashboard that has been built focuses on presenting data in the form of service performance to the public that has been carried out by LPKA Class 1 Palembang. In addition to processing data that is closely related to public services carried out by LPKA, the e-dashboard can also provide information to Andikpas' families about the details and status of Andikpas applications that have been made by Andikpas and visits that have been received by Andikpas. In other words, the e-dashboard that has been built can visualize public service data owned by LPKA and present it in a better form that can be used by the Head of Prisons in making decisions related to the performance of services that have been carried out by LPKA Class 1 Palembang. In addition to obtaining information in the form of the performance of the work unit that is external because it is related to the outside community, the head of the prison also requires the presentation of information on the performance of the work unit under him which is internal, especially in terms of monitoring employee performance. Monitoring is an effort carried out regularly to identify the implementation of various programs as determined, the timing of program implementation as scheduled, and progress in achieving program objectives [10] (Asia and the Pacific Program of Educational Innovation for Development., \& Unesco. (1987). Coping with dropout: A handbook. Bangkok: Unesco Regional Office for Education in Asia and the Pacific.). With monitoring, the routine process of collecting data and measuring progress on program objectives or monitoring changes that focus on processes and outputs can be achieved [11].

To monitor the performance of LPKA employees in each field, the Head of each Division and the Head of the Prison see the work of their subordinates through reports and documentation of daily activities sent by their employees via messages on Whatsapp. In addition to activity reports that are difficult to trace back, the superiors also find it difficult to see the progress of activities carried out by employees in carrying out certain activities so as to allow for reporting of activities that are repeated or which take too long to progress. Supervision of daily activities carried out by LPKA employees needs to be carried out to predict the level of achievement of government agencies in being accountable for the successful implementation of the obligations mandated to these agencies. Thus, strengthening supervision and strengthening performance accountability can be carried out in order to achieve the realization of WBK and WBBM.

This study aims to develop an electronic dashboard on the Class 1 LPKA Palembang found in previous studies [5] by improving it according to the feedback provided by users and adding functions in the form of reporting and monitoring the daily activities of LPKA Class 1 Palembang employees.

\section{PREVIOUS RESEARCH}

The research of Tomczak et al [12] offers monitoring of employee performance using evidencebased techniques with a tool in the form of Electronic Performance Monitoring (EPM). The EPM used in the form of security cameras to GPS tracking systems with data collected in real-time can be used for performance appraisal, training and development, logistics tracking, employee health and safety programs. The use of EPM for monitoring employee performance has previously been carried out by Bhave [13] by looking at the relationship between the frequency of using EPM and employee performance in 2 field studies. The results of the study indicate that the use of EPM is often associated with performance benefits for the organization, especially in employee task performance and Organizational Citizenship Behaviors (OCB). 
The next research was carried out by Rahardja et al [14], namely developing a dashboard for monitoring the performance of accountants on web based online accounting in universities. Web Based Accounting Online is an online accounting system that is used to facilitate employee performance in managing finances in an agency. The developed dashboard provides information in the form of user actions in conducting financial transactions. Research by Wagimin et al [15] built a monitoring system for employee competency certification at PT PLN (Persero) West Kalimantan Region. Monitoring of competency certification is aimed at increasing the company's growth in managing resources and increasing competitiveness by taking into account the types of competencies that must be developed in an organization.

Research related to monitoring employee performance was carried out by Romzi et al [16] with the object of research being the traffic officer of the Central Lombok Regency Transportation Service. The results of the study are in the form of an application that can be used to monitor the location of employees by utilizing Google Maps and GPS on Android-based mobile phones.

\section{RESEARCH METHODOLOGY}

The stages of research carried out in improving the electronic dashboard at LPKA Class 1 Palembang are:

1. Explore user feedback on the e-dashboard that has been developed. This is done to see the accuracy of the e-dashboard that has been built according to the user's needs according to the access rights at each level. The results of this stage are in the form of feedback which is used as the basis for improving the e-dashboard to make it more in line with user requests and needs.

2. Make improvements to the e-dashboard according to the feedback provided by users and add the function of reporting and monitoring the daily activities of LPKA Class 1 Palembang employees. At this stage, software development (system) is carried out with the following stages:

\section{a. Planning}

At this stage, an analysis of the functional requirements of the system is carried out based on the feedback that has been obtained as well as planning for the addition of new system functional requirements in the form of reporting on the daily activities of LPKA employees.

\section{b. Designing}

For standardization in the documentation of the system development, at this stage a modeling of the functional requirements of the system is carried out on a blueprint that will be used as a reference in making the system.

\section{c. Coding}

At this stage the coding of the system is carried out by translating the blueprints that have been made in the previous stage into the appropriate programming language to produce a system according to the desired platform. At this stage, direct testing of all components contained in the system is also carried out to see whether all of its functions have worked as expected.

\section{d. Testing}

Testing at this stage is carried out to see user responses in using the system that has been built. Testing is carried out using the User Experience Questionnaire to measure user experience in using the system.

\section{RESULTS AND DISCUSSIONS}

In the early stages of the research, re-socialization of the e-dashboard that had been built in the previous iteration of system development was carried out. This is done to explore feedback from users and adapt to the needs of new users in accordance with the new system users (admins) due to employee rotation as well as new regulations and policies. The functional requirements of the e-dashboard developed in the previous stage are shown using the Use Case diagram in Figure 1.

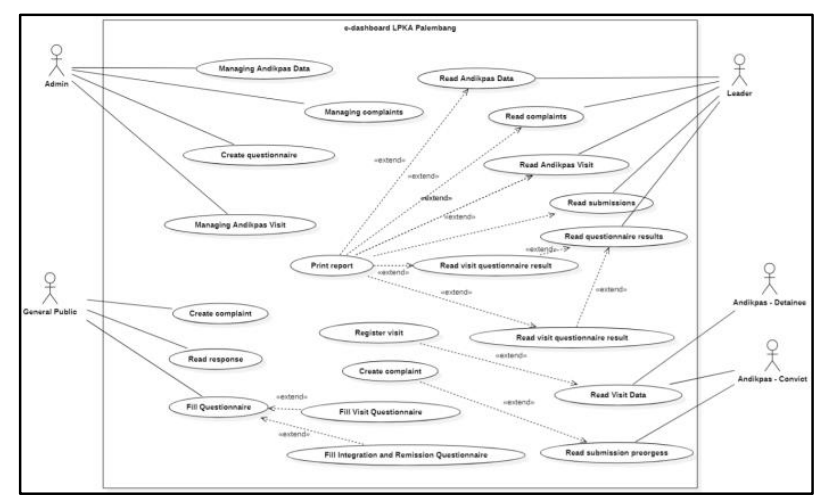

Figure 1 E-Dashboard Use Case Diagram Developed in Previous Stages [5].

The method used at this stage is direct exposure to the functions contained in the system. The socialization activities shown in Figure 2 produce a summary of the results of obtaining feedback from system users and employees of LPKA Class 1 Palembang, namely:

1. Dividing functions on functional requirements in accordance with the main tasks of the field or section contained in LPKA Class 1 Palembang.

2. Complaints are addressed directly to the https://www.lapor.go.id/ site, so that complaints 
from the general public can be linked to the web link and are no longer managed internally.

3. Remove the access rights of the questionnaire freely without logging into the system. The questionnaire can only be accessed by Andikpas or Andikpas' family through access rights, so that the questionnaire can only be accessed when Andikpas has logged into their account.

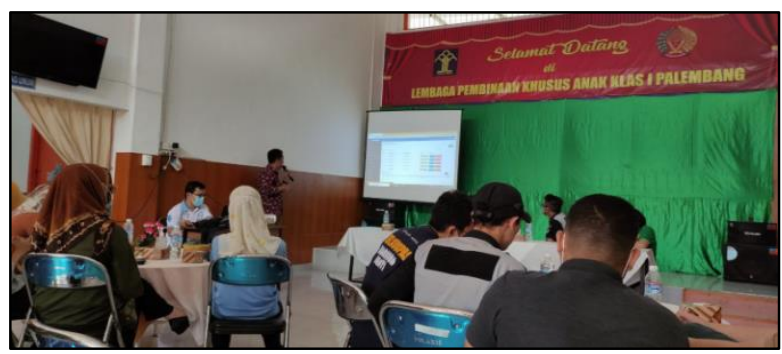

Figure 2 Socialization Activities and Exploring EDashboard System User Feedback.

The next stage is to make improvements to the edashboard system by paying attention to the feedback that has been given by system users and planning to add new e-dashboard functions.

\section{Planning}

At the planning stage, the functional requirements of the system are outlined in a Use Case diagram with several revisions and improvements from the previous system functional requirements which are shown in Figure 1. The Use Case diagram generated at this stage is shown in Figure 3.

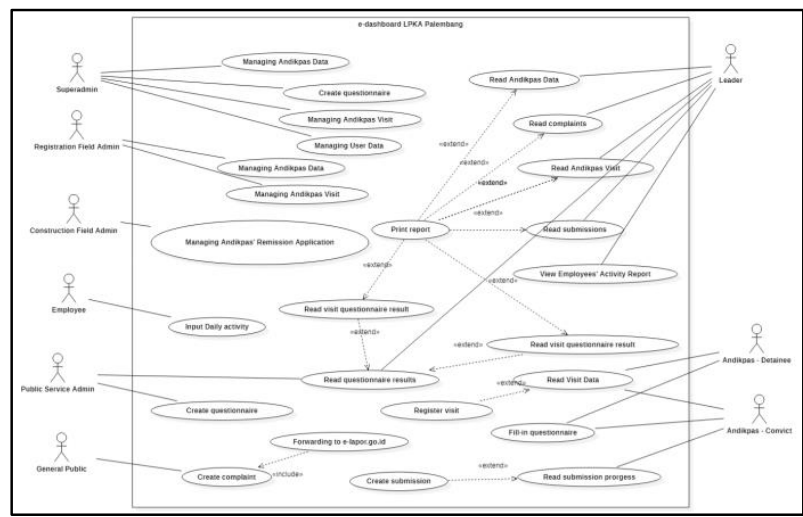

Figure 3 Use Case Diagram for E-Dashboard System Repaird.

From Figure 3, it can be seen that there are several types of new access rights, namely access rights for the field of guidance in managing applications for remission, assimilation, leave before release, leave to visit family, and conditional leave carried out by Andikpas; access rights for the field of public services that have access rights to manage questionnaire questions; access rights for the registration field that have access rights to register and manage Andikpas data; and access rights for public services to manage questionnaire questions and view the assessment of the questionnaires filled out by Andikpas (family).

The next revision was carried out by eliminating the complaint function on the functional requirements of the system and directing complaints directly to the web https://www.lapor.go.id/, as well as transferring the access rights for filling out the questionnaire to the Andikpas access rights so that Andikpas and their families were able to fill out the questionnaires. the.

\section{Designing}

The design stage begins with changing the database model in previous studies [17] by adjusting the data to be used in the new system. Improvements to the new database (Figure 4) are the existence of several tables that are used to accommodate daily activity data along with descriptions, progress on each date, and attachments of supporting documents for the implementation of these daily activities. The new database also eliminates the table used to accommodate complaint data from the general public due to the elimination of the complaint management function from the general public.

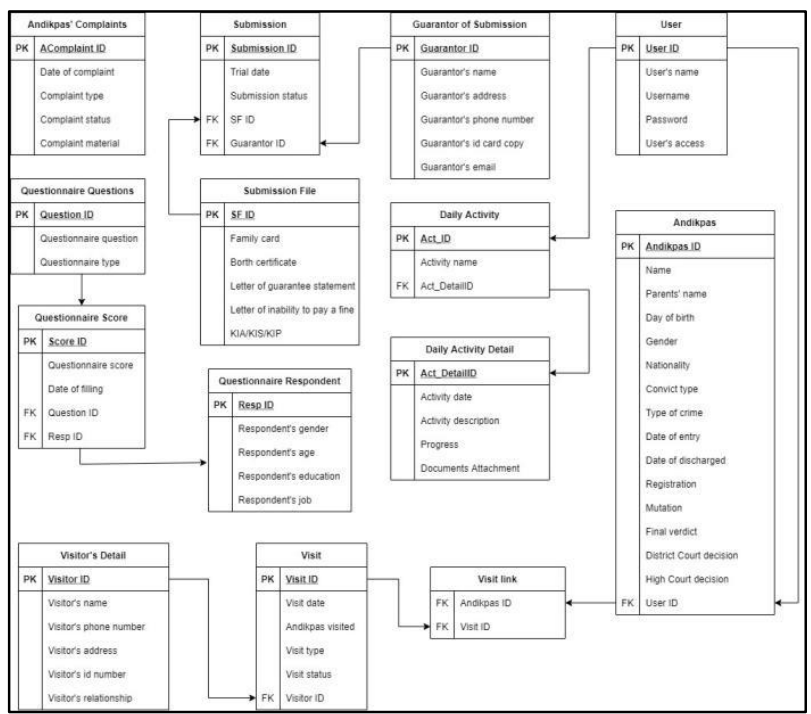

Figure 4 Logical Database Design for E-Dashboard System Improvement.

The next design is done to model the system structure from class definition. Modeling is done by defining the objects contained in the system and making blueprints using Class Diagrams. The class diagram for improving the e-dashboard system is shown in Figure 5. The change in the class diagram in Figure 4 with the previous e-dashboard class diagram [5] is that there is a class that can be called to manage daily activity report data that can be filled in by employees and can be accessed (read) by his superiors. In addition, there was a deletion of classes used to manage complaint data by the general public because this function was no longer needed in the system. 


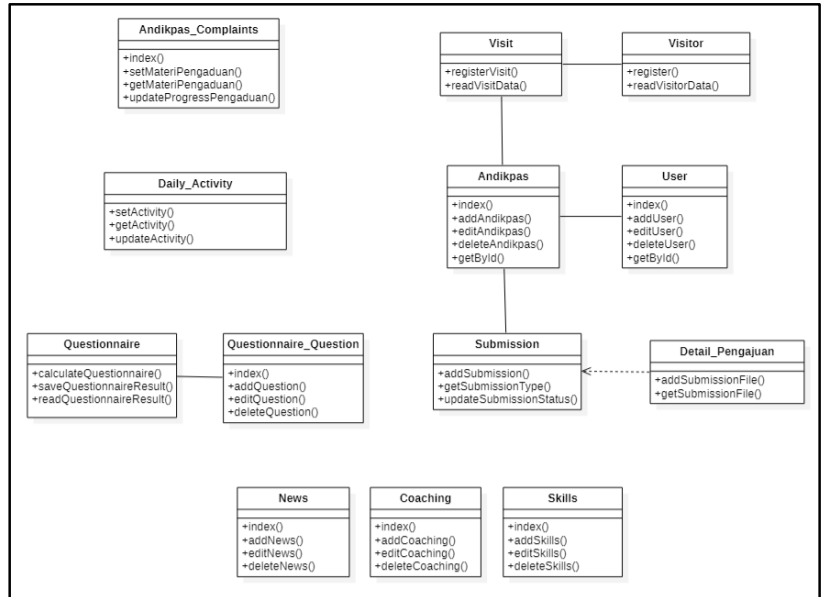

Figure 5 E-Dashboard Class Diagram.

\section{Coding}

The results of the design in the previous stage are used as a blueprint in coding so that the resulting system is in accordance with the functional requirements of the system that has been planned. The results of the implementation on the web page in adding daily activities with LPKA employee access rights are shown in Figure 6.

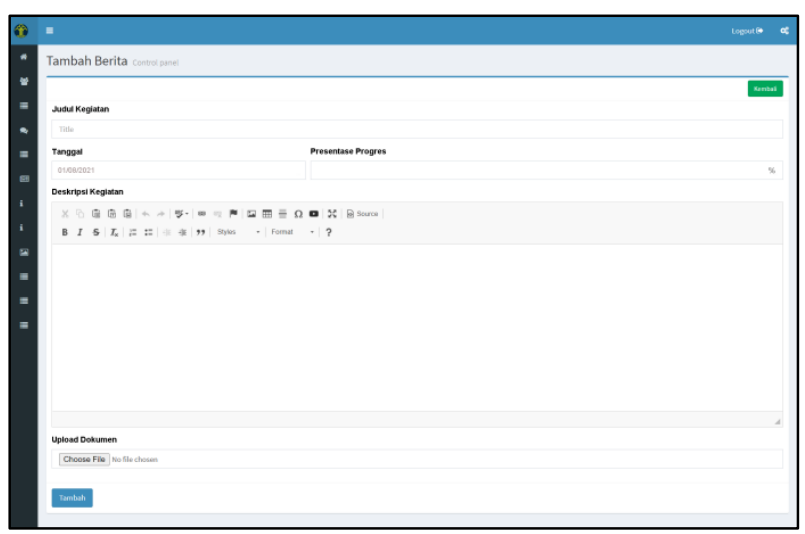

Figure 6 Coding Results of Daily Performance Reporting Pages.

In terms of access rights as superiors, superiors can monitor by tracking the length of time an activity is completed and ensuring that no activities are reported repeatedly.

\section{Testing}

The test was conducted to measure the perception and response of users of the improved e-dashboard system. The method used at this stage of testing is the User Experience Questionnaire (UEQ), which is a user experience measurement method introduced by Dr. Martin Schrepp [18]. UEQ measures the perception of system users based on 6 scales, namely Attractiveness, Perspicuity, Efficiency, Dependability, Stimulation, and Novelty. Respondents used were LPKA Class 1 Palembang employees with 39 respondents.

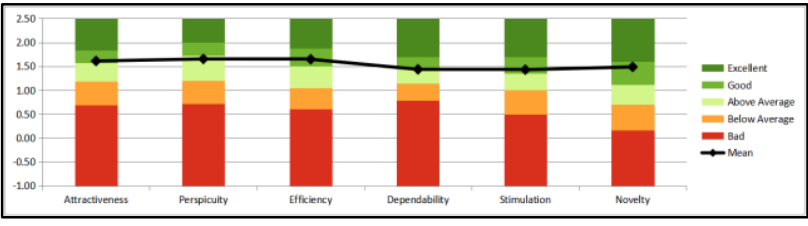

Figure 7 New E-Dashboard User Experience Measurement Results.

Figure 7 shows the results of measuring user experience in using the developed e-dashboard system. Based on these calculations, the user gives a Good value for the attractiveness, efficiency, stimulation, and novelty scales with the values being 1.61, 1.65, 1.43, and 1.49, respectively. Meanwhile, on the Perspicuity and Dependability scale, the results of the user response measurement obtained the Above Average criteria with values of 1.65 and 1.44 .

\section{CONCLUSIONS AND LIMITATIONS}

The research conducted repairs and modifications of the e-dashboard system found in LPKA Class 1 Palembang by adjusting the functional requirements of the system with user needs as well as new regulations or policies at LPKA. Modifications were made by eliminating general access in filling out the questionnaire so that only users who have access as Andikpas can fill it out, removing the complaint function by the general public and directing it to the https://lapor.go.id web, as well as adding a daily activity reporting function by every employees whose progress can be seen by the employee's immediate supervisor. The results of the user experience measurement of the edashboard system obtained a Good value in terms of attractiveness, efficiency, stimulation, and novelty, as well as Above Average in terms of Perspicuity and Dependability.

In the next research, further analysis can be done regarding the user experience measurement results that have been obtained through the UEQ method. Despite obtaining an Above Average rating, the results of measuring user experience on the Perspicuity and Dependability scales have the lowest values compared to other scales. To explore in more detail about this scale, further measurements can be made or by using other methods and techniques to determine the cause of the user's level of difficulty in using the e-dashboard system and what kinds of interactions cannot be controlled by the user.

\section{ACKNOWLEDGMENTS}

The researchers thank Ristekdikti-BRIN for funding this research with the contract number 308/SP2H/LT/DRPM/2021. 


\section{REFERENCES}

[1] A. S. Hanafi and M. Harsono, "Pelaksanaan Reformasi Birokrasi Dengan Pembangunan Zona Integritas Pada Kementerian Perindustrian," J. Inf. dan Komun. Adm. Perkantoran, vol. 4, no. 1, pp. 31-37, 2020.

[2] Tarsi, "Membangun Zona Integritas Dunia Peradilan Menuju WBK dan WBBM," 2020. https://www.pasemarang.go.id/images/stories/Artikel/1MEMBANGUN_ZONA_INTEGRITAS_DUNI A_PERADILAN.pdf (accessed Sep. 01, 2021).

[3] C. Ramadani, "LAPAN Agam Menuju Birokrasi Bersih dan Melayani," Buletin LAPAN, vol. 6, no. 1, pp. 34-36, 2019.

[4] E. F. Setiawan, "Strategic Perubahan Organisasi Dalam Meningkatkan Predikat WBK di Lapas Kelas IIA Cibinong," Bus. Manag. Econ. Account. Natl. Semin., vol. 1, no. 1, pp. 14361448, 2020.

[5] H. Hadiwijaya, F. Febrianty, and R. A. Azdy, "Development of Prototype Electronic Dashboard Service Performance of LPKA Class I Palembang," Sinkron, vol. 5, no. 2, pp. 294304, 2021, doi: 10.33395/sinkron.v5i2.10779.

[6] A. Janes, A. Sillitti, and G. Succi, "Effective Dashboard Design," Cut. IT J., vol. 26, no. 1, pp. 17-24, 2013.

[7] S. Few, Information Dashboard Design. O’Reilly Media, 2006.

[8] W. Eckerson, Performance Dashboards. Measuring, Monitoring, and Managing your Business., 2ns ed. Hoboken: Wiley, 2011.

[9] S. Malik, Design and Best Practices for IT. Hoboken: Wiley, 2005.

[10] UNESCO, Asia adn Facific Programme of Educational Innovation Development Coping With Drop Out: A Hand Book. Bangkok: UNESCO Regional Office For Education In Asia adn Facific, 1987.
[11] Jumri and J. Purnama, "Perancangan Sistem Monitoring Konsultasi Bimbingan Akademik Mahasiswa dengan Notifikasi Realtime Berbasis SMS Gateway,” J. Sist. dan Teknol. Inf., vol. 1, no. $1,2012$.

[12] D. L. Tomczak, L. A. Lanzo, and H. Aguinis, "Evidence-based recommendations for employee performance monitoring," Bus. Horiz., vol. 61, no. 2, pp. 251-259, 2018, doi: 10.1016/j.bushor.2017.11.006.

[13] D. P. Bhave, "The Invisible Eye? Electronic Performance Monitoring and Employee Job Performance," Pers. Psychol., vol. 67, no. 3, pp. 605-635, 2014.

[14] U. Rahardja, Q. Aini, and A. Khoirunisa, "Monitoring Kinerja User Akuntan Menggunakan Dashboard Pada Web Based Accounting Online di Perguruan Tinggi," $J$. Inform., vol. 18, no. 2, pp. 162-174, 2018, doi: 10.33372/stn.v4i2.406.

[15] Safriadi, H. Nasution, and N. Safriadi, "Rancang Bangun Sistem Informasi Monitoring Sertifikasi Pegawai Berbasis Web pada PT PLN (Persero) Wilayah Kalimantan Barat," J. Sist. dan Teknol. Inf., vol. 5, no. 3, pp. 206-210, 2017.

[16] R. Romzi, W. Bagye, A. Tantoni, and H. Fahmi, "Monitoring Kinerja Pegawai Bidang Lalu Lintas Dinas Perhubungan Kabupaten Lombok Tengah Berbasis Android," J. Inform. dan Rekayasa Elektron., vol. 2, no. 1, pp. 46-51, 2019, doi: 10.36595/jire.v2i1.89.

[17] H. Hadiwijaya, F. Febrianty, and R. A. Azdy, "Database Design for Child Special Development (Case Study: Palembang Child Special Development Institution )," Atl. Highlights Eng., vol. 7, pp. 542-549, 2021, [Online]. Available: https://www.atlantispress.com/proceedings/first-t1-t220/125952499.

[18] M. Schrepp, User Experience Questionnaire Handbook. Germany, 2018. 